\title{
Karakterisasi Adsorben Kulit Durian Tanpa Modifikasi dan Termodifikasi dengan Pelapisan Lateks untuk Penyerapan Rhodamin B
}

\author{
Hadistya Suryadri ${ }^{1}$, Lince Muis ${ }^{2}$, dan Ronado Lingga ${ }^{3}$ \\ ${ }^{1,2,3}$ Program Studi Teknik Kimia, Fakultas Teknik, Universitas Jambi, Muaro Jambi, Indonesia \\ Email: hadistya.suryadri@gmail.com, ilincemuisismet@yahoo.co.id, ronadolinggaa@gmail.com
}

\section{Info Artikel}

Diterima: 12 Agustus 2019

Disetujui: 26 Agustus 2019

Dipublikasikan: 29 Agustus 2019

\section{Alamat Korespondensi: \\ hadistya.suryadri@gmail.com \\ Copyright (C) 2019 Jurnal \\ Engineering}

This work is licensed under the Creative Commons Attribution International License (CC BY 4.0).

\begin{abstract}
Abstrak
Kulit durian memiliki potensi yang besar untuk dimanfaatkan sebagai adsorben dalam meminimalisir zat pewarna Rhodamin B sebelum dibuang ke lingkungan melalui proses adsorpsi. Lateks diketahui memiliki stabilitas dan kekuatan mekanik yang baik. Oleh karena itu, modifikasi adsorben kulit durian terlapisi lateks dilakukan dengan harapan mampu meningkatkan daya adsorpsi. Daya adsorpsi ditinjau dengan membandingkan karakteristik yang dihasilkan antara adsorben kulit durian tanpa modifikasi dengan adsorben kulit durian yang dimodifikasi dengan pelapisan lateks. Dilakukan analisa SEM untuk mengetahui morfologi adsorben dan analisa EDS untuk melihat unsurunsur yang terdapat pada adsorben. Dari hasil analisa terbukti bahwa retakan dan patahan yang terbentuk pada adsorben kulit durian tanpa modifikasi diperbaiki dengan pelapisan lateks, menghasilkan pori-pori yang terdistribusi merata dengan ukuran paling kecil 2,814 $\mu \mathrm{m}$ dan paling besar 4,110 $\mu \mathrm{m}$ serta kadar unsur karbon berjumlah 69,27\%. Adorben yang dihasilkan kemudian diuji kinerjanya pada penjerapan zat pewarna rhodamin B dalam kondisi asam. Ketika penjerapan, adsorben terlapisi membentuk gumpalan dan tidak terjadi penjerapan. Karakteristik adsorben setelah penjerapan dianalisa menggunakan SEM-EDS, diketahui bahwa akibat terjadinya penggumpalan lanjutan terbentuk pori-pori berukuran kecil padahal kadar unsur karbon yang terdapat pada adsorben berjumlah besar yaitu 82,35\%.
\end{abstract}

Kata kunci: kulit durian; adsorben; lateks; rhodamin B

\section{Pendahuluan}

Durian (Durio Zibenthinus Murr.) merupakan tumbuhan tropis Asia Tenggara yang termasuk dalam famili Bombacaceae dan bergenus Durio. Buah durian berbentuk bulat panjang dan bulat tidak beraturan. Buah akan matang dan siap dipetik pada usia kurang lebih empat bulan setelah bunga mekar. Waktu pembungaan dan kematangan buah durian dipengaruhi oleh ketinggian tempat tanaman durian. Idealnya dibutuhkan tempat dengan ketinggian 50-600 mdpl, berintensitas cahaya matahari $40-50 \%$ dengan suhu $22-30^{\circ} \mathrm{C}$. Di 
Indonesia tanaman durian tersebar di Pulau Sumatera, Jawa, Kalimantan dan sebagian Pulau Papua dengan jumlah total produksi durian sebesar 567.519 ton pada tahun 2011 (Wiryanta, B.T Wahyu, 2008 dan Santoso, Panca Jarot, 2012). Menurut Amiza dkk, 2004 dalam Ahmad, Mohd Azmier dkk, 2015, diketahui bahwa dalam satu buah durian sekitar $70 \%$ bagiannya merupakan kulit durian dan biji durian, yang mana bagian tersebut seringnya tidak termanfaatkan. Jika dihitung dari total produksi durian pertahun ada sekitar 397.263 ton jumlah residu kulit durian dan biji durian yang dalam praktiknya dibakar ataupun dibuang langsung di tempat pembuangan sampah. Kedua hal tersebut merupakan solusi yang tidak baik, pembakaran sampah menghasilkan asap yang mengandung zat berbahaya dan menimbulkan pecemaran udara, sedangkan pembuangan residu durian ke Tempat Pembuangan Akhir (TPA) akan memperbesar volume sampah dan meyebabkan terjadinya over-capacity pada TPA. Oleh karena itu diperlukan upaya eksploratif yang mampu memberikan solusi yang andal dan terpercaya sebagai alternatif pemanfaatan residu durian.

Rhodamin B merupakan zat pewarna sintetik berbentuk serbuk kristal, tidak berbau, berwarna merah keunguan pada konsentrasi tinggi dan berwarna merah terang pada konsentrasi rendah. Zat pewarna sintetik ini banyak digunakan dalam industri tekstil, percetakan, dan industri kulit. Jika dibandingkan dengan pewarna alami, zat pewarna sintetik memiliki daya mewarnai kuat, stabil dan tahan terhadap lingkungan, akan tetapi sangat sulit didegradasi secara alami. Sehingga diperlukan upaya untuk meminimalisir jumlah zat pewarna Rhodamin B sebelum dibuang ke lingkungan agar tidak mencemari perairan dan menimbulkan efek toksik jika masuk ke tubuh manusia (Kurniasih, Mardiyah dkk, 2014; Sahara, Emmy dkk, 2018; dan Olsy, Fradilla dkk, 2018). Beberapa upaya yang telah dilakukan adalah metode adsorpsi, filtrasi, flokulasi, pemisahan dengan membran, koagulasi, presipitasi secara kimia, oksidasi biologi, ion exchange, reverse osmosis dan solvent extraction. Metode adsorpsi lebih banyak diminati karena memiliki sistem operasi yang mudah, efisiensi cukup baik, ekonomis dan layak untuk diterapkan pada skala besar. Apalagi dalam beberapa tahun terakhir, telah ditemukan bahwa limbah perkebunan yang murah dan sangat berlimpah bisa dijadikan adsorben yang sangat efisien untuk memurnikan air yang tercemar (Shah, Jasmin dkk, 2013 dan Nhung, Nguyen Thi Hong dkk, 2018)

Pemanfaatan kulit durian sebagai adsorben telah banyak dilakukan (Tham dkk, 2010, Tanasale, Matheis F.J.D.P dkk, 2014; Marlinawati dkk, 2015; Masyithah, Cut dkk, 2018) dengan melihat potensi kulit durian yang mengandung karbon cukup tinggi (dapat dilihat pada tabel 1) sehingga memenuhi syarat sebagai adsorben. Pori-pori karbon terlebih dahulu diaktivasi untuk memperluas pemukaan adsorben dan meningkatkan daya adsorpsi. Aktivasi dapat dilakukan secara fisika dan kimia. Jika dilakukan aktivasi kimia, digunakan zat pengaktivasi (aktivator) dengan senyawa asam ataupun basa. Molekul-molekul aktivator akan teradsorpsi oleh bahan karbon dan melarutkan pengotor yang berada pada pori-pori karbon seperti mineral-mineral anorganik dan memperluas pori-pori karbon.

Tabel 1. Analisis proksimat dan ultimat kulit durian (Tham dkk, 2010)

\begin{tabular}{cc|ccccc}
\hline \multicolumn{2}{c|}{ Analisis Proksimat (\%) } & \multicolumn{5}{|c}{ Analisis Ultimat (\%) } \\
\hline Moisture content* $^{*}$ abu $^{* *}$ & $\mathrm{C}$ & $\mathrm{H}$ & $\mathrm{N}$ & $\mathrm{S}$ & $\mathrm{O}$ \\
11,27 & 4,84 & 39,30 & 5,90 & 1,00 & 0,06 & 53,74 \\
\hline
\end{tabular}

${ }^{\star}$ dasar basah; ${ }^{\star \star}$ dasar kering 
Adsorpsi zat pewarna sintetik seperti methylen blue, Acid Blue 113 dan Direct Violet 51 menggunakan lateks telah dilakukan oleh peneliti (Gupta, V.K. dkk, 2011; Johns, Jobis dan Rao, Vijayalakshmi, 2011; Utara, Songkot dan PiawPhatai, 2013; Lopes da Silva, Lucimara dan Galembeck, Fernando, 2015; serta Hasanudin, Nurul Hasliza dkk, 2017). Lateks merupakan polimer alami, digunakan untuk mendesain struktur berpori dan permukaan bermofologi yang banyak digunakan dalam berbagai aplikasi. Lateks dapat digunakan langsung sebagai adsorben ataupun dipadukan dengan adsorben lainnya seperti clay/lateks, NR (natural rubber)/Ag, NR/karbon aktif komersial, NR/Halloysite Nanotube, $N R /$ chitosan. Penggunaan lateks sebagai adsorben diketahui dapat meningkatkan stabilitas termal dan karakteristik mekanik pada paduan adsorben bahkan pada adorben clay/lateks menghasilkan ikatan adhesi dan ikatan kation yang kuat dalam mengadsorpsi zat warna methylen blue.

Penelitian ini bertujuan mempelajari karakteristik adsorben yang terbuat dari kulit durian dan adsorben kulit durian yang dimodifikasi dengan pelapisan lateks. Kedua adsorben tersebut dibandingkan kinerjanya terhadap adsoprsi zat pewarna Rhodamin B.

\section{Metode Penelitian}

\subsection{Alat dan Bahan}

Peralatan penelitian meliputi: Scanning Electron Microscopy- Energy Dispersive Spectroscopy (SEM-EDS), tanur, oven, grinder, ayakan 120 mesh, neraca analitik, desikator, kertas saring Whatman 42, hotplate, stirrer corong dan alat-alat gelas yang umum digunakan di laboratorium.

Bahan yang digunakan pada penelitian meliputi: kulit durian, $\mathrm{HCl}, \mathrm{NaOH}$, akuades, larutan $\mathrm{CaCl}_{2}$ dan $\mathrm{Na}_{2} \mathrm{CO}_{3}$.

\subsection{Pembuatan Karbon Berpori dari Kulit Durian}

Kulit durian yang digunakan pada penelitian ini diambil dari sekitar kota Jambi. Kulit durian dibersihkan dan dikeringkan dibawah sinar matahari hingga beratnya konstan. Kulit durian kemudian dipotong-potong dan dioven selama 15 menit. Selanjutnya kulit durian di grinder dan diayak menggunakan ayakan 120 mesh. Setelah didapatkan ukuran yang diinginkan, kulit durian di karbonisasi menggunakan tanur pada suhu $250^{\circ} \mathrm{C}$ selama 15 menit.

\subsection{Proses Aktivasi Adsorben}

Proses aktivasi dilakukan dengan merendam 20 gram karbon berpori dari kulit durian dalam larutan $\mathrm{HCl}$ $0,1 \mathrm{M}$ selama $2 \mathrm{jam}$. Dilakukan penyaringan dan kemudian pencucian dengan akuades sehingga dicapai $\mathrm{pH}$ 7. Selanjutnya, adsorben yang telah diaktivasi tersebut dioven pada suhu $110^{\circ} \mathrm{C}$ selama \pm 1 jam. Dilakukan analisa menggunakan SEM-EDS untuk adsorben sebelum terlapisi lateks (adsorben non-modifikasi)

\subsection{Proses Pelapisan Kulit Durian dengan Lateks}

Sebanyak 12 gram lateks ditetesi $\mathrm{Na}_{2} \mathrm{CO}_{3}$ dengan konsentrasi $20 \%$ sejumlah $2 \%$ dari berat total lateks. Setelah itu, ditambahkan 12 gram serbuk kulit durian. Selanjutnya, larutan campuran tersebut diteteskan ke dalam $100 \mathrm{ml}$ larutan $\mathrm{CaCl}_{2}$ dan dibiarkan selama 24 jam untuk menyempurnakan pembentukan. Kemudian larutan campuran tersebut dicuci sampai $\mathrm{pH}$ netral, dikeringkan dan disimpan dalam desikator. Karakteristik adsorben kulit durian dan lateks (adsorben modifikasi) dilakukan dengan menggunakan SEMEDS. 

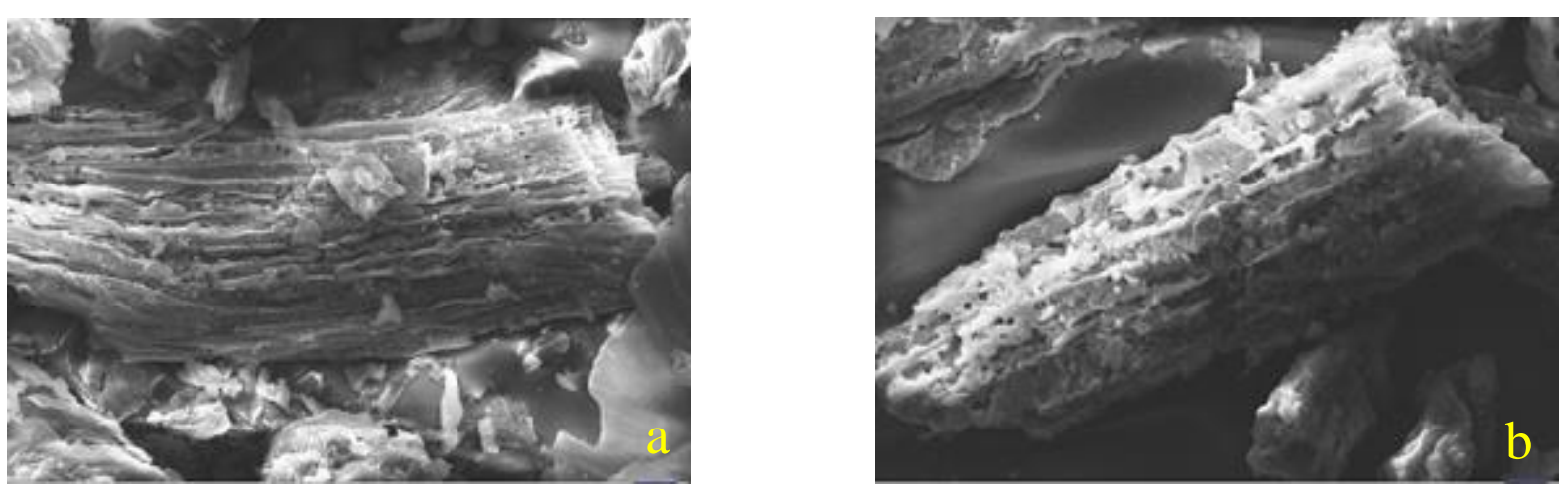

Gambar 1. Hasil analisis SEM dengan perbesaran 500x (a) adsorben kulit durian non-modifikasi (b) adsorben kulit durian terlapisi lateks

\subsection{Proses Adsorpsi Zat Pewarna Rhodamin B pada Keadaan Asam}

Zat pewarna Rhodamin B yang digunakan dalam proses adsorpsi dibuat dengan melarutkan kristal Rhodamin B sejumlah 0,001 gram dalam $1000 \mathrm{ml}$ air (konsentrasi 10 ppm). Kemudian disiapkan erlenmeyer $100 \mathrm{ml}$ yang berisikan adsorben modifikasi terlapisi lateks serta $25 \mathrm{ml}$ larutan Rhodamin B. Proses adsorpsi dilakukan dalam kondisi asam dan dengan pengadukan yang berlangsung selama 60 menit.

\section{Hasil Penelitian dan Pembahasan}

Secara visual berdasarkan hasil analisis SEM yang ditunjukkan gambar 1 terdapat pori-pori pada adsorben dari kulit durian tanpa modifikasi maupun adsorben modifikasi terlapisi lateks. Tetapi, pori-pori pada adsorben terlapisi lateks tampak hampir pada semua sisi adsorben atau dapat dikatakan terdistribusi secara merata. Selain itu struktur adsorbennya juga lebih kokoh, tidak terdapat agglomerasi, retakan maupun patahan. Kemudian, jika dibandingkan dari ukuran pori-pori, adsorben kulit durian terlapisi lateks berukuran lebih besar dibandingkan ukuran pori-pori pada adsorben kulit durian tanpa modifikasi. Ukuran pori-pori pada adsorben terlapisi lateks berukuran paling kecil $2,814 \mu \mathrm{m}$ dan paling besar $4,110 \mu \mathrm{m}$ sedangkan ukuran pori-pori paling kecil pada adsorben tanpa modifikasi yaitu 938,1 nm dan ukuran pori paling besar yaitu 3,038 $\mu \mathrm{m}$. Hal ini menunjukkan bahwa dengan pelapisan lateks, struktur dan morfologi dari adsorben kulit durian tanpa modifikasi diperbaiki karena lateks memiliki sifat menstabilkan seperti terjadi di penelitian yang dilakukan oleh Hasanudin, Nurul Hasliza dkk, 2017 pada adsorben NR (natural rubber)/Ag dan NR/Halloysite Nanotube. Lateks mampu menstabilkan partikel paduannya pada adsorben tersebut melalui koordinasi dengan grup amina dari protein yang secara alami dimiliki oleh lateks. Adsorben Fe-Al-Ce yang didapatkan pada penelitian oleh Wu dkk, 2008 sangat mudah muncul retakan karena tersusun dari partikel yang kaku, kemudian ditambahkan lateks yang berfungsi sebagai pengikat pada adsorben tersebut sehingga stabilitasnya meningkat. Sehingga dapat disimpulkan dengan penambahan lateks retakan yang terjadi dapat dikurangi atau bahkan dapat dihilangkan.

Sifat-sifat yang dimiliki oleh lateks tersebut bisa muncul karena adanya proses penggumpalan lateks menggunakan $\mathrm{CaCl}_{2}$. Menurut Abu Bakar dkk, 2007 pada proses penggumpalan lateks akan mengeluarkan air yang terkandung di dalamnya dan hanya meninggalkan protein yang teradsorpsi kuat pada permukaan lateks. Kemudian, terbukanya rantai protein pada permukaan lateks mengkonformasi sisi yang bersifat hidrofobik dan hidrofilik untuk berkontak dengan fasa aqueous dan non-aqueous yang berakibat gugus 
fungsionalnya berperan sebagai pengikat pada permukaan karet. Telah kita ketahui pula bahwa jenis gugus fungsional akan mempengaruhi daya adsorpsi dan daya adsorpsi yang kuat tentunya membutuhkan stabilitas yang tinggi.

Analisis EDS yang menggambarkan unsur-unsur pada adsorben ditampilkan pada gambar 2 . Berdasarkan analisis, terdapat karbon pada adsorben tanpa modifikasi dan adsorben terlapisi lateks dengan jumlah besar, yaitu 71,26\% dan 69,27\%. Munculnya unsur klorin pada adsorben terlapisi lateks dikarenakan adanya penambahan $\mathrm{CaCl}_{2}$ sebagai koagulan, hal ini juga diikuti dengan bertambahnya jumlah kadar kalsium pada adsorben terlapisi lateks yaitu berjumlah 3,09\%, sedangkan kadar kalsium pada adsorben tanpa modifikasi berjumlah $1,14 \%$. Unsur-unsur lain seperti magnesium, kalium, sulfur dan fosfat merupakan indikasi adanya kandungan abu baik pada adsorben kulit durian tanpa modifikasi maupun adsorben kulit durian terlapisi lateks. Komposisi tiap unsur tersebut disajikan pada tabel 2.
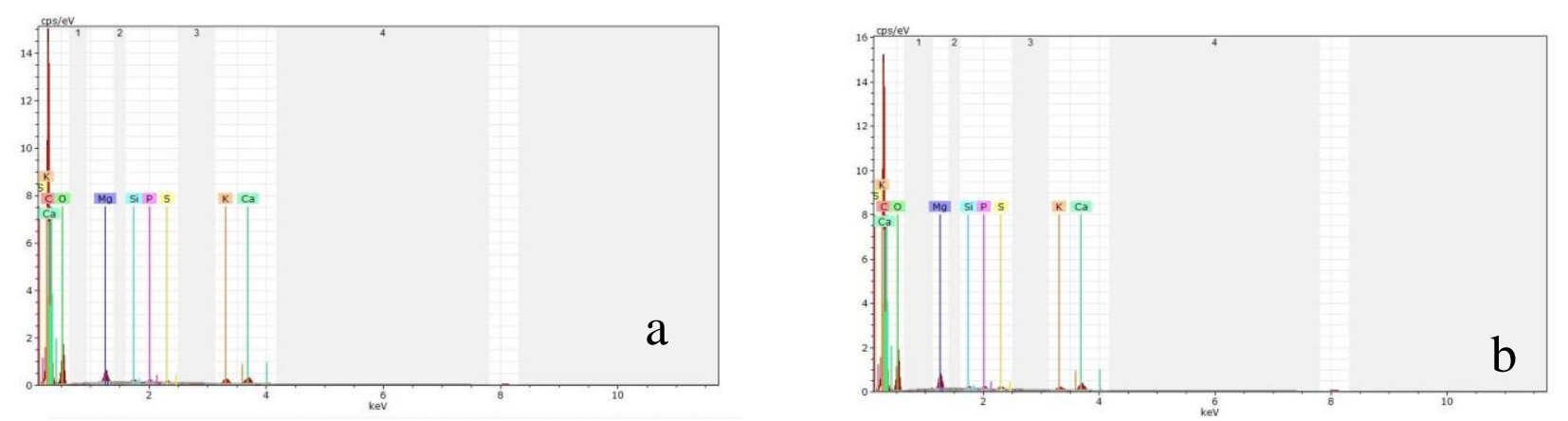

Gambar 2. Hasil analisis EDS (a) adsorben kulit durian non-modifikasi (b) adsorben kulit durian terlapisi lateks.

Tabel 2. Kadar Unsur Pada Adsorben

\begin{tabular}{cccc}
\hline \multirow{2}{*}{ No. } & Unsur & \multicolumn{2}{c}{ Kadar (\%) } \\
\cline { 3 - 4 } & & \multicolumn{1}{c}{$\mathrm{a}^{*}$} & $\mathrm{~b}^{\star *}$ \\
\hline 1 & $\mathrm{C}$ & 71,26 & 69,27 \\
2 & $\mathrm{O}$ & 25,59 & 25,34 \\
3 & $\mathrm{Mg}$ & 0,95 & 0,40 \\
4 & $\mathrm{Si}$ & 0,14 & 0,12 \\
5 & $\mathrm{P}$ & 0,15 & 0,21 \\
6 & $\mathrm{~S}$ & 0,12 & 0,18 \\
7 & $\mathrm{Cl}$ & - & 1,21 \\
8 & $\mathrm{~K}$ & 0,64 & 0,17 \\
9 & $\mathrm{Ca}$ & 1,14 & 3,09 \\
\hline
\end{tabular}

$\mathrm{a}^{\star}$ : adsorben kulit durian tanpa modifikasi

$\mathrm{b}^{* *}$ : adsorben kulit durian terlapisi lateks 

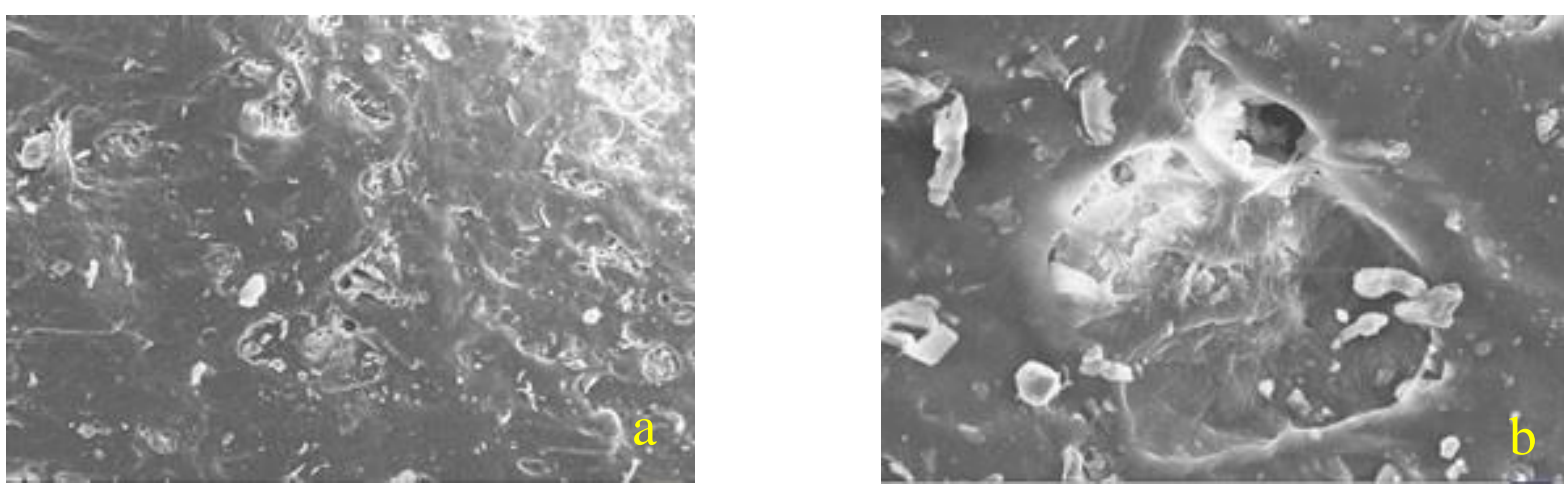

Gambar 3. Hasil analisis EDS pada adsorben terlapisi lateks setelah proses penjerapan (a) dengan perbesaran 100x (b) dengan perbesaran 500x

Setelah didapatkan adsorben dilakukan uji kinerja adsorben pada penjerapan zat pewarna Rhodamin B dengan pengadukan selama 60 menit dan dalam kondisi asam. Namun, ketika adsorben terlapisi lateks berkontak dengan larutan Rhodamin B tersebut, adsorben menggumpal serta tidak ada penjerapan yang terjadi. Oleh karena itu dilakukan analisa untuk melihat perubahan yang terjadi pada morfologi adsorben terlapisi lateks. Gambar 3 merupakan hasil analisis SEM untuk adsorben setelah proses adsorpsi.

Secara visual morfologi yang ditunjukkan pada hasil analisis SEM, permukaan adsorben tidak terdapat patahan ataupun retakan dan terdapat sedikit lubang-lubang berukuran kecil. Jika lubang-lubang ini bisa dianggap pori, maka didapat ukuran pori terkecil yaitu $558,5 \mathrm{~nm}$ dan ukuran pori terbesar yaitu 2,122 $\mu \mathrm{m}$. Jadi, jika terdapat pori-pori maka seharusnya terjadi proses penjerapan Rhodamin B, dalam penelitian ini tidak terjadi dikarenakan dengan ukuran pori-pori yang kecil maka tentunya luas permukaannya akan kecil sehingga penjerapannya menjadi tidak efisien. Kadar karbon yang ditunjukkan pada gambar 4 dan tabel 3 memiliki jumlah yang lebih besar dibandingkan karbon pada adsorben sebelum proses penjerapan, yaitu berjumlah $82,35 \%$. Namun tingginya kadar karbon yang tidak diikuti dengan luas permukaan yang tinggi menyebabkan proses penjerapan tidak efektif.

Adsorben menggumpal dan sedikit sekali pori-pori yang tampak mungkin terjadi karena adanya peristiwa penggumpalan lanjutan pada lateks. Karena baik $\mathrm{HCl}$ maupun $\mathrm{CaCl}_{2}$ merupakan zat yang bisa digunakan dalam penggumpalan lateks, meskipun dengan mekanisme yang berbeda. Pada penggunaan $\mathrm{HCl}$, penggumpalan terjadi karena penurunan $\mathrm{pH}$ sedangkan pada penggunaan $\mathrm{CaCl}_{2}$ terjadi karena penambahan kation garam sebagai elektrolit yang berlawanan pada partikel karet. Penggumpalan lateks menggunakan asam berjalan lebih cepat dibandingkan menggunakan garam organik. (Handayanii, 2014 dan Karunaratne dan Piyadasa, 1973 dalam Suwardin, Didin dan Purbaya, Mili., 2015).

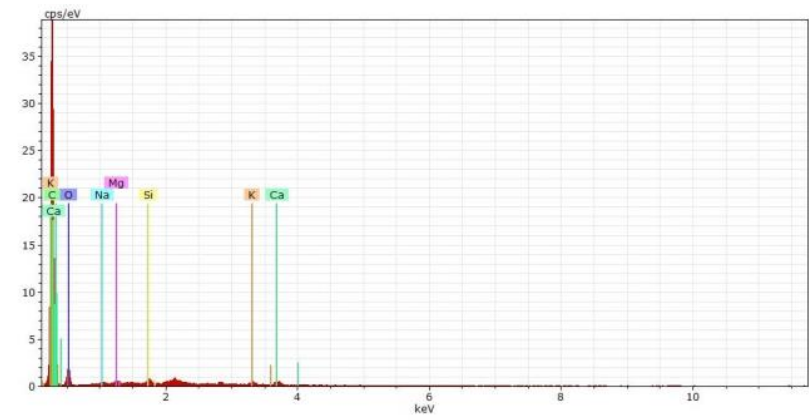

Gambar 4. Hasil analisis EDS pada adsorben terlapisi lateks setelah proses adsorpsi. 
Tabel 3. Kadar Unsur pada Adsorben Terlapisi Lateks Setelah Proses Adsorpsi

\begin{tabular}{ccccccc}
\hline \multicolumn{7}{c}{ Kadar Unsur (\%) } \\
\hline $\mathrm{C}$ & $\mathrm{O}$ & $\mathrm{Mg}$ & $\mathrm{Si}$ & $\mathrm{K}$ & $\mathrm{Ca}$ & $\mathrm{Na}$ \\
82,35 & 15,72 & 0,25 & 0,36 & 0,44 & 0,21 & 0,22 \\
\hline
\end{tabular}

\section{Kesimpulan}

Adsorben kulit durian tanpa modifikasi diperbaiki strukturnya dengan pelapisan lateks sehingga retakan dan patahan yang terdapat pada adsorben diubah menjadi struktur yang lebih kokoh, sifat-sifat tersebut meningkatkan stabilitas adsorben dan tentu saja akan meningkatkan daya adsorpsi.

Diharapkan dapat dilakukan proses penjerapan Rhodamin B dalam keadaan basa untuk mengetahui kinerja adsorben berdasarkan kapasitas penjerapannya.

\section{Daftar Pustaka}

[1] Abu Bakar, NHH., Ismail, J., Abu Bakar, M. (2007). Synthesis and characterization of silver nanoparticles in natural rubber. Materials Chemistry and Physics, 104, 276-283.

[2] Ahmad, Mohd Azmier., Ahmad, Norhidayah., Bello, Olugbenga Solomon. (2015). Modified durian seed as adsorbent for the removal of methyl red dye from aqueous solutions. Appl Water Sci, 5:407-423.

[3] Gupta, V.K., Guta, Bina., Rastogi, Arshi., Agarwal, Shilpi., Nayak, Arunima. (2011). A comparative investigation on adsorption performances of mesoporous

[4] activated carbon prepared from waste rubber tire and activated carbon for a hazardous azo dye-Acid Blue 113. Journal of Hazardous Materials 186, 891-901.

[5] Hasanudin, Nurul Hasliza., Chien, Tan Yee., Abidin, Asmaa' Zainal., Abu Bakar, Noor Hana Hanief., Leng, Tan Wei. (2017). Application of low cost natural rubber films for water remediation. Journal of Physical Science, Vol. 28(3), 81-94.

[6] Handayani, Hani. (2014). Pengaruh berbagai jenis penggumpal padat terhadap mutu koagulum dan vulkanisat karet alam. Jurnal penelitian Karet. 32 (1), 74-80

[7] Johns, Jobis dan Rao, Vijayalakshmi. (2011). Adsorption of methylene blue onto natural rubber/chitosan blends. International Journal of Polymeric Materials, 60:766-775.

[8] Kurniasih, Mardiyah., Riapanitra, Anung., Rohadi, Anas. (2014). Adsorpsi rhodamin B dengan adsorben kitosan serbuk dan beads kitosan. Sains \& Mat, Vol. 2 No. 2: 27-33.

[9] Lopes da Silva, Lucimara dan Galembeck, Fernando. (2015). Morphology of latex and nanocomposite adsorbents prepared by freeze-casting. J. Mater. Chem. A, 3, 7263-7272.

[10] Marlinawati., Bohari, Yusuf., Alimuddin. (2015). Pemanfaatan arang aktif dari kulit durian (durio zubethinus L.) sebagai adsorben ion logam cadmium (II). Jurnal Kimia Mulawarman, volume 13, Nomor 1.

[11] Masyithah, Cut., Aritonag, Barita., Gultom, Erdiana., (2018). Pembuatan arang aktif dari limbah kulit durian sebagai adsorben pada minyak goreng bekas untuk menurunkan kadar asam lemak bebas dan bilangan peroksida. Jurnal Kimia Saintek dan Pendidikan, Vol 2, No 2: 66-67. 
[12] Nhung, Nguyen Thi Hong., Quynh, Bui Thi Phuong., Thao, Pham Thi Thu. (2018). Pretreated Fruit Peels as Adsorbents for Removal of Dyes. IOP Conf. Series: Earth and Environmental Science, 159.

[13] Olsy, Fradilla., Saputra, Edy., Helwani, Zuchra. (2018). Kesetimbangan Adsorpsi Zat Pewarna Rhodamine-B Menggunakan Fly Ash Sawit Sebagai Low-cost Adsorbent. JOM FTEKNIK, Volume 5, Edisi 1 Januari s/d Juni 2018.

[14] Sahara, Emmy., gayatri, Putu Sri., Suarya, Putu. (2018). Adsorpsi zat warna rhodamin B dalam larutan oleh arang aktif batang tanaman gumitir teraktivasi asam fosfat. Cakra Kimia (Indonesian E-Journal of Applied Chemistry), Vol 6 Nomor 1.

[15] Santoso, Panca Jarot. (2012). Tabloid SinarTani. Edisi 19-25 No.3487 Tahun XLIII. Badan Litbang Pertanian.

[16] Shah, Jasmin., Jan, M. Rasul., Haq, Attaul., Khan, Younas. (2013). Removal of Rhodamine B from aqueous solutions and wastewater by walnut shells: kinetics, equilibrium and thermodynamics studies. Front. Chem. Sci. Eng, 7(4): 428-436.

[17] Suwardin, Didin., dan Purbaya, Mili. (2015). Jenis bahan penggumpal dan pengaruhnya terhadap parameter mutu karet spesifikasi teknis. Warta Perkaretan, 34 (2), 147-160.

[18] Utara, Songkot dan PiawPhatai. (2013). Adsorption characteristics of direct violet dye by natural rubber chips. Advanced Materials Research, Vol. 844, 391-394.

[19] Wiryanta, B.T Wahyu. (2008). Sukses Bertanam Durian. Jakarta: Agromedia Pustaka.

[20] Tanasale, Matheis F.J.D.P, Sutapa, I Wayan., Topurtawy, Ronald R. (2014). Adsorpsi zat warna rhodamin B oleh karbon aktif dari kulit durian (durio zibethinus). Ind. J. Chem. Res., 2, 116-121.

[21] Wu, Hai-Xia., Wang, Ting-Jie., Dou, Xiao-Min., Zhao, Bei., Chen, Lin., Jin, Yong. (2008). Spray coating of adsorbent with polymer latex on sand particles for fluoride removal in drinking water. Ind. Eng. Chem. Res, 47, 4697-4702.

[22] Tham, Y.J., Latief, Puziah Abdul, Abdullah, A.M.,Taufiq-Yap, Y.H. (2010). Physical characteristic of activated carbon from durian shell. Asian Journal of Chemistry, Vol. 22, No. 1, 722-780. 